bined with a ban on federal funding for human cloning imposed by Clinton at the same time, was considered by the senator to be sufficient. But, says Camp, Frist is now reconsidering his position in the light of Seed's announcement. "He is looking at legislation now. But it's with human cloning [for reproductive purposes]. He feels strongly about protecting research."

Behind the congressional inaction on cloning over the last ten months has been not only a busy schedule in which the issue got pushed aside, but also abortion politics, as exemplified in the fate of the Clinton bill (see Nature 387, 748; 1997).

Despite courting Republicans and Democrats in the House and Senate, and support for the bill's approach from groups such as the Biotechnology Industry Organization, the White House has been unable to find a sponsor for the bill. This is partly because the bill - like the recommendations of the NBAC - does not prohibit use of cloning techniques in human embryo research.

Even Connie Morella, the liberal Republican congresswoman who represents the Maryland constituency that includes the National Institutes of Health, has not stepped forward to sponsor the legislationalthough the White House courted her. Morella called last week for a bill to ban human cloning.

"Nobody in Congress wanted to touch [the Clinton bill] with a ten-foot pole," says Roger Pedersen, a mammalian embryologist at the University of California, San Francisco, who speaks for the Federation of American Societies for Experimental Biology (FASEB). The federation, which represents 52,000 sci-

\title{
Europe brings in first international ban
}

[PARIS] At a ceremony in Paris on Monday (12 January), 17

European countries signed a protocol added to the European Convention on Human Rights and Biomedicine that bans the use of human cloning for reproductive purposes - the first legally binding international agreement to do so.

Two countries were conspicuous by their absence among the signatories: the United
Kingdom and Germany. Neither can sign the protocol because they have not signed the convention itself, the United Kingdom because of delays caused by the change in government, and Germany because it feels the provisions in the convention concerning human embryo research and consent by incapacitated individuals are not strict enough.

ButBritish legislation setting up the Human Fertilization and Embryo
Authority already forbids the use of human cloning, and human cloning for reproductive purposes is banned by law in Germany.

The signing of the agreement was welcomed by Jacques Chirac, the French president. Speaking at a meeting of Europe's ethics committees in Paris, Chirac said that an international ban was essential as otherwise the technology would migrate to countries where regulation was less strict. Declan Butler

entists, is pushing a different approach. In September, following the lead of the Society for Developmental Biology, it adopted a voluntary moratorium on cloning.

Since then, the American Society for Reproductive Medicine, representing 9,000 fertility physicians, and the Society for the Study of Reproduction, with 2,400 members, have adopted the same moratorium. Pedersen says the opprobrium heaped on Seed by fellow scientists last week is evidence of the power of peer pressure in the face of aberrant behaviour. "There's a circling of the wagons, with him outside," he says.

Although FASEB does not condone human cloning at this stage, he adds, "Congress has been acting responsibly by not rushing legislation. Hastily written law can do more harm than good by deterring poten-

\section{Unesco declaration lacks legal teeth}

[PARIS] Richard Seed's declared intention to set up a cloning laboratory in Tijuana, Mexico, if the US Congress bans human cloning was quickly rebutted by the Mexican government, which lastFriday expressed its "broadest repudiation" of Seed's proposal.

But, like Seed's challenge to the US Congress, his offshore plans point out another reality: the international community has no solid legal front to present against the planned work of Seed or those who may follow him. Not only could Seed now proceed in Mexico - where the president of the national bioethics commission last week could only implore the Mexican
Congress to legislate on the matter - but no binding international ban on cloning is now in place.

The 186 member states of the United Nations Educational, Scientific and Cultural Organization unanimously passed a declaration in November calling for a cloning ban (see Nature 390, 110 \& 388, 508; 1997). But that declaration is not legally binding.

Noëlle Lenoir, the chairwoman of Unesco's International Bioethics Committee, says the committee cannot take a position on the need for a legally-binding international agreement, as it has frozen its activities pending a review of its functions to fulfil the new mandate given to it by Unesco of following up the implementation of the provisions of the declaration. The new committee, which should be in place next month, will probably consider whether a legal instrument is desirable.

Turning the call for a ban on cloning for reproductive purposes contained in the declaration into a legallybinding agreement may in practice change little, argues Lenoir. What is important is that countries translate international agreements into their national laws and enforce them. "Pressure for international agreements counts for little unless there is national government will to implement them." M.w.\&.D.B. tially beneficial research. That's why I think a voluntary moratorium is more effective."

But Capron of the NBAC says that congressional inaction has resulted in domestic and international US failures. Domestically, he says, it has allowed a "cowboy" like Seed to pursue his ends unchallenged. And internationally, the fact that the United States has not condemned human cloning officially by passing the Clinton legislation "means that we're not in a leadership position".

The Clinton legislation would ban the use of cloning to create children by anyone in the private or public sector. It would expire after five years, before which time the NBAC would be required to review developments and recommend whether the law should be extended. It includes explicit protections for cloning's research applications in DNA, cells, tissues and animals, but does not mention human embryo research. Embryo research - whether or not using cloning technology - is at present legal if financed privately, but barred from federal funding.

Scientific groups have said that they fear that, unlike the Clinton bill, those introduced by congressmen are so broadly worded and imprecise that they threaten research. A Senate bill introduced last February by Christopher Bond (Republican, Missouri) would bar the use of federal funds for "research with respect to the cloning of a human individual". Bond said last week that he would push for a broader "emergency ban" to encompass the private sector.

Two House bills were introduced last winter by Vern Ehlers. One banned federal funding for "research that involves the use of a human somatic cell for the process of producing a human clone". The other imposed a penalty of up to $\$ 5,000$ on anyone "producing a human clone". Ehlers later expanded the first bill to include a ban on use of cloning in human embryo research. The House Science Committee approved it last July; it had to be rewritten to win enough votes to be passed by the committee. 